\title{
Innovative Entrepreneurship Education Development
}

\author{
Fenglan Luo ${ }^{1, ~ a}$, Mingjun Chen ${ }^{2, b}$ \\ ${ }^{1}$ Business School, Jiangxi Science and Technology Normal University \\ ${ }^{2}$ Business School, Jiangxi Science and Technology Normal University \\ aluofl73@163.com, b2943192684@qq.com,
}

Keywords: Innovation and entrepreneurship, Development, Approach.

\begin{abstract}
Competition in the 21st century is the competition of talents. The most important thing for building an innovative country is to cultivate talent with innovative ability. In the current economic transformation and development environment, colleges and universities bear the burden of cultivating innovative entrepreneurship. On the basis of analyzing the experience of innovation and entrepreneurship education in China and abroad, the existing problems in the development of innovation and entrepreneurship education in China are discussed in this paper and the corresponding solutions are put forward. Innovation and entrepreneurship education is a kind of quality education aiming at all-round development, aiming at cultivating high-quality talents with innovation ability. It constructs an environment conducive to the development of students' creative ability, and emphasizing students' awareness of innovation, skills, thinking, emotion and personality education. Train students in the learning process the spirit of exploration, the courage to break the original frame, and the flexibility to apply the existing knowledge and wisdom to creatively solve problems. Explore new laws and new methods, create new ideas and continue to reform and innovation according to actual needs so as to achieve the purpose of cultivating innovative spirit.
\end{abstract}

\section{The characteristics of innovative entrepreneurship education}

\section{A. Innovation and entrepreneurship education has strong advancement}

Innovation and entrepreneurship education is a cutting-edge new educational philosophy, which is focused on the future trend of education and is in full compliance with the spirit of the times.

\section{B. Innovation and entrepreneurship education has practicability}

Innovation and entrepreneurship education build a practical platform for students to comprehensively promote teaching practice, emphasizing the practice of innovation mastery and entrepreneurship skills and training of social action. In practice, students learn social experience which is not in books and better adapt and integrate into society.

\section{Innovation and entrepreneurship education has flexibility}

There is no fixed pattern and method in innovation and entrepreneurship education. Educational activities will be updated and developed with the change of social environment to meet the learning needs of different students. Flexible design of education and teaching model is to achieve training and improving all aspects' ability of the students.

\section{Innovation and entrepreneurship education is scientific and systematic}

Innovation and entrepreneurship education is a complex and large system and a multi-level and three-dimensional education and teaching system. Innovation and entrepreneurship education involves all aspects of economy, society and culture, and its implementation requires not only the teaching and education of colleges and universities, but also the support and exchange between government and community. Through innovative ways of education, the scientific system of entrepreneurship education is played in good effect. 


\section{Successful development of innovation and entrepreneurship education at home and abroad}

\section{A. Innovation and entrepreneurship education development in foreign developed countries}

Innovation and entrepreneurship education research and practice in Europe and the United States and other developed areas started earlier, and the system is matured with a high level of scientific research and rich practical experience.

The United States was the first country to create innovative educational programs. Since 1947, innovation and entrepreneurship education reform is initiated. After 1975, Bill Gates, as the representative of technological innovation entrepreneur, set off "Entrepreneurial Revolution", which effectively promoted the development of innovation and entrepreneurship education in colleges and universities. Innovation and entrepreneurship education has more than 60 years of history, and has more than 1,800 institutions of innovation and entrepreneurship education institutions, which opened a total of more than 3,000 entrepreneurship courses and more than 60 kinds of innovative business education related academic journals. Its theoretical research and practice are in the forefront of the world and its innovative business education theory has also formed a fairly complete system.

Britain's economy has been at a low level due to the economic crisis in mid-1970s and the unemployment rate has been increasing. The concept of higher education in the UK gradually changed from the cultivation of students' knowledge and ability to the stimulation of students' innovative potential. British innovation and entrepreneurship education development plan came into being, which opened the forward door of British innovation and entrepreneurship education. University students' innovation and entrepreneurship project was officially launched in 1982 in the United Kingdom. Through entrepreneurial education lectures and student employment guidance, finally examine the students' innovative entrepreneurial ability. The project has a strong utilitarian purpose, so the one-sided concept lacks development momentum. In the 21st century, with the development of British society, British gradually realized that utilitarian innovation and entrepreneurship education cannot meet the needs of the times and individual needs of students. Entrepreneurship education goals are changed to cultivate the quality of entrepreneurs, emphasizing that the transfer of general knowledge should integrate work-related learning. Innovative entrepreneurship education points to the construction of innovative cultural atmosphere and creative business education has made great progress in curriculum, practice and management.

In addition, Japan and Singapore have gradually put innovation and entrepreneurship education into education system among people. Institutions of higher learning not only have strong research team, but established innovative entrepreneurship research fund for students to carry out innovative entrepreneurial practice experience activities.

In addition, innovative entrepreneurship education development in France, New Zealand, Canada and other countries is also in full swing.

\section{B. The experience of domestic innovation and entrepreneurship education development}

In 1989, innovation and entrepreneurship education was first introduced. But until the early 21st century, innovation and entrepreneurship education gradually rose. In 2002, the Ministry of Education participated in "Challenge Cup" competition for college students' entrepreneurship education. In the same year, "Innovative Entrepreneurship Education" pilot forum was put forward. "Innovative entrepreneurship education is to cultivate high quality talents with innovative spirit and creative ability, which is an important task of higher education. Entrepreneurship education is an inevitable measure for comprehensive improvement of national quality and for the deepening of education systems reform. It is an epoch-making pioneering work." Ministry of Education listed Tsinghua University, Shanghai Jiaotong University, Wuhan University and some other institutions as China's innovation and entrepreneurship education pilot colleges and universities for experimental college students' innovation and entrepreneurship education. In 15 years from 2002 to 2017, with economic and social development need and the continual phenomenon of college students' unemployment with the passage of time, college students' innovation and entrepreneurship education began to gradually gain attention and get development. 
At present, China's college students innovation and entrepreneurship education has formed three classic models:

The first model takes the People's University of China as the representative. Classroom teaching-oriented innovation and entrepreneurship education model is used to promote the combination of second classroom and first classroom. The second class is to start successful entrepreneurs' lectures, innovation and entrepreneurship project competition and other forms. The first classroom is college students' entrepreneurial guidance courses. The two are effectively combined to achieve students' enhanced sense of innovation and entrepreneurship and build students innovative business knowledge structure.

The second is based on Tsinghua University and Shanghai Jiaotong University, an education model focusing on students' basic quality in actual combat. The model is based on quality education, life-long education and innovative education and it provides business capital and necessary technical advisory services for college students. The purpose is to cultivate the innovative spirit and entrepreneurial ability of college students in comprehensive innovation and entrepreneurship education model, which more completely establishes the basic framework and content of innovation and entrepreneurship education.

The third is based on Beijing University of Aeronautics and Astronautics and Zhejiang University, which is an innovation and entrepreneurship education model focusing on improving students' innovative knowledge and entrepreneurial skills. The model established a special business management training school institutions through campus business combined with University of Science and Technology Park, teaching students how to start business and provide funds for entrepreneurship and some consulting services. Give students innovative entrepreneurship guidance and practice so that students can begin to adapt to social competition ahead of time and help students quickly improve their personal entrepreneurial survival capacity.

\section{Current problems in innovative entrepreneurship education development in China}

\section{A. College students have weak innovative business awareness}

Relevant data show that less than $5 \%$ of national college students in school participate in innovation and entrepreneurship activities or scientific research activities. Students generally believe that scientific research innovation or entrepreneurship is of distance from them, and innovation and entrepreneurship education does not matter. It can be seen that the innovation consciousness of college students is weak. There are some deviations in innovation and entrepreneurship awareness, and their enthusiasm for innovation and entrepreneurship is not high. There is still a big gap between the existing situation and the requirements of the times.

\section{B. The technical content of college students' innovative educational activities is not high}

Carry out innovative activities competition with innovation and innovation as the main content. The purpose is to create a good foundation for future innovation and entrepreneurship. However, a survey found that a large part of award-winning works of professional college students in innovative competition of relevant professional college students are teacher-guided works and students' independent innovation is not high. Most of the innovative results are from the guidance of college teachers. Apart from participating in national or provincial competitions, colleges and universities have very few innovative activities organized by themselves and the number of students participating in the innovation activities is very small.

\section{The innovation and entrepreneurship education in colleges and universities is not deep enough}

According to relevant survey, most of innovative entrepreneurship education in colleges and universities are in forms of separate educational activities such as lectures, extracurricular activities, entrepreneurial policy guidance and entrepreneurial assistance consultation, which fails to integrate with personnel training system of colleges and universities. It is lack of substantive content and 
knowledge system in education and teaching. Traditional ideological education is inculcation-based, and most of them are stagnated in operational level and skills level, lacking innovation and entrepreneurial value lead for students. The degree of attention for colleges and universities to carry out innovation and entrepreneurship education is not enough, and innovation and entrepreneurship education concept are not in enough depth. Colleges and universities still take innovative and entrepreneurial education as a kind of utilitarian activities, lacking concerns for innovation and entrepreneurial motivation of students, their innovation and entrepreneurship awareness and ideals. The majority of colleges and universities carry out innovative entrepreneurship education activities only to solve the employment difficulties and it is education activity only for a small number of outstanding students. As colleges and universities innovation and entrepreneurship education is still stagnant in the shallow, and the activities of innovation and entrepreneurship education in colleges and universities cannot be carried out in depth.

\section{The path of innovation and entrepreneurship education in China}

\section{A. Establish sound innovation and entrepreneurship education system}

Innovative entrepreneurship education system includes innovative entrepreneurship education practice system and innovation and entrepreneurship education security system. Through the improvement of innovation and entrepreneurship education practice system, design and development series of innovative entrepreneurship practice courses, so that students can be in practice to get rich practical experience and make students work from theory to practice. The combination of theory and practice makes students to experience the environment so as to accumulate experience and improve the quality of innovation and entrepreneurship. Sound innovation and entrepreneurship education security system first requires straightening out the mechanism, making clear division of responsibilities, and forming clear and clear work processes. In addition to improve the relevant rules and regulations, establish relevant support system for innovative entrepreneurship education to provide institutional protection.

\section{B. Improve innovation and entrepreneurship education evaluation mechanism}

The quality of college students' innovation and entrepreneurship should pay attention to the mastery of innovation and entrepreneurship knowledge, and pay attention to comprehensive and coordinated development of college students' innovative ability and quality, and establish a comprehensive assessment method. The traditional examination method is changed into innovative research projects and business projects assessment, which pays attention to the method and process in solving practical problems. The spirit of innovation and entrepreneurial capacity are put into the assessment index system to solve practical problems. According to the characteristics of innovation and entrepreneurship education, teachers' performance should be evaluated from the aspects of teaching attitude, teaching process and teaching effect. We should not only pay attention to the final evaluation, but also pay attention to process evaluation. Around the establishment of innovative entrepreneurial talent training system, evaluate the teacher's innovative entrepreneurial teaching quality evaluation through school, college, and students, and ensure the objectivity of teaching quality evaluation.

\section{Actively use the Internet to expand innovation and entrepreneurship education teaching approach}

The establishment of innovation and entrepreneurship teaching platform based on university campus network makes use of modern network technology pioneering innovative entrepreneurship education space and channels, and perform innovation and entrepreneurship teaching in line with the reality. Teachers and students make online exchange and students do self-learning. Through the innovation of entrepreneurship education courses' online learning knowledge, ideological exchange, simulation practice, quality improvement, innovative business teaching platform can effectively enhance the spirit of innovation of college students and improve the quality of college students' 
innovation and entrepreneurship.

\section{Cultivate innovative culture on campus and establish innovative ideas of entrepreneurship education}

Innovation and entrepreneurship education can really promote the development of society. The key lies in that whether there is a strong atmosphere of innovation and entrepreneurship culture in the campus, and the educational philosophy behind it. In addition, students' recognition of innovation and entrepreneurship is also affected by the concept of innovation and entrepreneurship education. Innovative entrepreneurship education should be based on the relevant policies of serving students and motivating college students to innovate independently. Relying on the professional characteristics of each college, the characteristics of school personnel training are combining with all-round and multi-angled concept of innovative entrepreneurship education and campus culture together to mobilize the entrepreneurial enthusiasm of college students.

\section{E. Enhance the quality of innovative entrepreneurship education faculty}

The faculty quality in innovating entrepreneurship education determines the success or failure of innovation and entrepreneurship education. Strengthen the training of teachers and entrepreneurship awareness and teachers' innovation and entrepreneurship professional training so that teachers can in person practice and truly experience innovation and entrepreneurship, and establish teachers innovative entrepreneurship education evaluation mechanism in order to drive teachers to improve the ability of innovation and entrepreneurship education and improve innovation and entrepreneurship education faculty quality.

\section{References}

[1] Liu Fucai, Wang Faming. Innovative education in colleges and universities: rational reflection and practice direction [J]. Journal of National School of Education, 2016

[2] Ji Hong. Innovative entrepreneurship education application under the perspective of application type talents [J]. Jiangsu Higher Education, 2016 (4).

[3] Wang Hu. The exploration and practice of college students' innovative entrepreneurship education model ---- A case study of Chinese language and literature major in Sichuan Foreign Studies University [J]. Journal of Literature and Education, 2017 (1).

[4] He Xuan. Guangxi university innovation and entrepreneurship training in China ---- ASEAN regional economic background [J]. Education Observations, 2017 (5). 